\title{
COOPERATION AND CONFLICT - THE BRITISH ARMY, THE NATAL GOVERNMENT AND THE PROSECUTION OF NATAL REBELS DURING THE ANGLO-BOER WAR
}

\section{Johan Wassermann \\ Faculty of Education, University of KwaZulu-Natal}

\section{Introduction}

The Natal Afrikaner ${ }^{1}$ rebels hardly feature in the historiography of the Anglo-Boer War of 1899-1902. The Times History of the War in South Africa dismisses their rebellion in one sentence, ${ }^{2}$ while the Natal Mercury of 25 April 1900 correctly points out that the number of rebels and the scale of the rebellion are rather insignificant when compared with that of the Cape Colony. In the latter, where in contrast to Natal, Afrikaners formed the bulk of the white population, the dynamics of the rebellion was very different. The large number of Afrikaners resident in the Cape Colony acted as a magnet for the Republican forces and as a result, large numbers of Afrikaners took up arms against Britain. From their side, the British authorities acted with a vengeance towards the Cape rebels, executing and imprisoning large numbers. ${ }^{3}$

While the rebellion in Natal, a region in which Afrikaners formed a significant minority amongst the white population, was much smaller in scale when compared to the Cape Colony it was nevertheless a war-related event of gigantic proportions for both the inhabitants of the Colony of Natal and the Natal Government. It was to spark

1. In this article, the term 'Boer' will be used to refer to citizens of the two Boer Republics and 'Afrikaner' to refer to Dutch-speaking British subjects resident in Natal and the Cape. This decision is based on the terms of description used by the bulk of the archival material consulted for this article.

2. LS Amery (ed.), The Times History of the War in South Africa 1899-1902, Vol VI, p. 62 .

3. Natal Mercury, 25.4.1900. For a comprehensive overview of the legal treatment of rebels during the Anglo-Boer War in the Cape Colony, see JH Snyman, Rebelleverhoor in Kaapland gedurende die Tweede Vryheidsoorlog met spesiale verwysing na die militêre howe (1899-1902), passim. 
debates about the kind of legal action that should be taken against the rebels and who should control the legal process. On the other hand, the British Army wanted to win the war against the two Boer Republics as speedily and with as little civilian interference as possible.

This article explores the multifaceted relationship between the powerful British Army, which had the capacity and ability to impose and administer martial law, and Natal, one of the smallest colonies in the British Empire with its limited capacity to dispense law, but unfailing belief in its own jurisdiction. This spawned both conflict and compromise on the legal procedures to be followed in dealing with Natal Afrikaner rebels accused of high treason. As such, this article is a case study of the coexistence of both military and civilian law in a theatre of war.

\section{The initial legal reaction from the Natal Government and the British Army}

Although the involvement of Natal Afrikaners, as British subjects, in the Boer invasion of the Colony and the subsequent subjugation of the Klip River County ${ }^{4}$ in October 1899 did not catch the Natal Government totally by surprise, its legal and preventative measures were slow in coming and hardly adequate. Martial law was only declared in all of Natal on 23 October 1899, more than 10 days after war broke out ${ }^{5}$ with the purpose of acting as "the public law of self-defence (and) the right to use military means to preserve the peace against public enemies within". ${ }^{6}$ Martial law gave the military authorities the power to use extreme measures to maintain safety and security. To achieve this, movement was restricted, passes were issued, people were arrested and removed from their farms, and property was commandeered. ${ }^{7}$ In Natal, martial law was initially upheld by the Indemnity Bill published on 5 June 1900 to protect "the Governor of the Colony, and the Officer Commanding her Majesty's Forces in Natal, and all persons acting under their authority and in good faith in regard

4. The Klip River County covered the whole of Northern Natal and consisted of the following districts: Newcastle, Dundee, Umsinga, Ladysmith and parts of Upper Tugela. The vast majority of the white inhabitants of these districts were Afrikaners who were British subjects. The Boers occupied this area for 188 days.

5. Pietermaritzburg Archive Repository (hereafter PAR), Government House (hereafter GH) 1454: Proclamation No. 108 extending martial law to all of Natal, Proviso B and Zululand, 23.10.1899; De Natal Afrikaner, 23.10.1899; Natal Witness, 24.10.1899. 6. FN Wiener, Civilians under military justice. The practice since 1869 especially in North America, p. 219.

7. PAR, Umsinga Magistrate (hereafter 1/UMS) 38: Pass issued to L Combrinck by T Maxwell, 18.9.1900; British Parliamentary Papers (hereafter Cd) 981: Papers relating to the administration of martial law in South Africa, 1902. 
to acts during the existence of Martial Law". ${ }^{8}$ This bill was subsequently updated by other Indemnity Bills as circumstances changed. ${ }^{9}$

The Natal Government's first reaction after war broke out was not the declaration of martial law. Instead, they swiftly issued several proclamations to suppress possible rebellion. ${ }^{10}$ Suspecting that the proclamations were being ignored, and disregarding the possibility that they may not have reached the people they were aimed at, the Natal authorities requested Attorney-General Henry Bale to prepare a draft proclamation that would allow the Natal Government to confiscate movable and immovable property of Natal Afrikaners who had been captured as prisoners-of-war (hereafter POWs) while fighting for the Boers, of those who died on the battlefield, and of the fathers who had sons on commando. In the proposed proclamation, the Governor of Natal, Sir Walter Hely-Hutchinson, prohibited the registrar of deeds to register the sale, transfer or mortgage of any of the properties registered in the names of Afrikaners in the abovementioned categories. ${ }^{11}$

The possible confiscation of rebel property as a punitive measure for committing high treason was at this early stage also one of the legal avenues investigated by the military. An enquiry by General Sir Redvers Buller, the officer commanding the British Army in South Africa at the time, to the War Office in London about how severely he should deal with those guilty of treason, elicited the following answer: "they are not entitled to favourable consideration and should be punished severely." This could include possible forfeiture of property and/or deportation. ${ }^{12}$

Attorney-General Bale was, however, personally hesitant when it came to punishing high treason by property confiscation. Quoting from the Groot Placaat Boek, Vol 6, p. 577, published on 1 May 1732, he indicated that the Netherlands had abolished confiscation of property altogether in the case of treason. Similarly, in the United Kingdom, Acts 33 and 34 abolished the confiscation and forfeiture of property for the same crime. Bale, nonetheless, contextualised the abolishment of confiscation

8. Public Record Office - Kew, London (hereafter PRO), Colonial Office (hereafter CO) 179/211: Indemnity Bill as published on 5.6.1900.

9. PAR, Prime Minister (hereafter PM) 34: Indemnity Bills, Act 41 of 1901 and Act 22 of 1902 .

10. See, for example, PAR, Natal Colonial Publication (hereafter NCP) 6/1/1/52: Proclamation No. 106 issued by W Hely-Hutchinson, 15.10.1899; Natal Witness, 16.10.1899.

11. PAR, Colonial Secretary's Office (hereafter CSO) 2581: Draft proclamation suggesting that it is the intention of the Natal Government to confiscate the property of rebellious Natal Afrikaners, 21.10.1899.

12. PRO, War Office (hereafter WO) 1767: Telegrams exchanged between General R Buller and the War Office, 11.12.1899. 
by stating that this did not apply to the property of rebels taken in the course of hostilities that would, under International Law, belong to the government. ${ }^{13}$

Despite the opinion of the Attorney-General, the Natal Government forged ahead with proposed legislation to sanction the official confiscation of property as a punishment for treasonable offences. ${ }^{14}$ Such thinking did not find favour with the Colonial Office or Secretary of State, Joseph Chamberlain, who asked for the opinion of the Law Officers' Department at the Royal Courts of Justice. Their report echoed the opinion earlier expressed by Attorney-General Bale, namely that neither under Roman Dutch Law nor under International Law could the Natal Government be justified in confiscating landed property for the crime of high treason. It would also be contrary to the principles of justice to pass a law that would sanction retrospective action for the purpose of inflicting such punishment. Suspected rebels could, however, be tried by martial law or treated as POWs. After the conclusion of the war, such rebels could then be tried for treason. ${ }^{15}$ The Natal Prime Minister, Albert Hime, responded by immediately abandoning the idea of property confiscation by declaring, "It is not the intention of the Government to introduce a bill to provide for confiscation as it is not one of the punishments recognised by the Law of this Colony or of England."16

At the same time as property confiscation was rejected as a sentence for high treason the death penalty as a form of punishment came under the spotlight. AttorneyGeneral Bale noted, "the principal punishment (for high treason) is doubtless that of death." He nevertheless argued against this because he viewed the death penalty to be very similar to confiscation. Bale therefore reasoned that a fine might be imposed as the punishment for high treason. However, he was quick to point out that fines were not the only way to punish treason and that the "primary punishment" was still death or imprisonment. ${ }^{17}$ Nonetheless what Bale did was, from the perspective of the Natal Government, to effectively remove the death penalty early on from the agenda as a punitive measure for high treason.

Where then did the Natal Government, roughly three months after the Boer invasion of Natal, stand on the punishment of high treason? Martial law had been declared, proclamations warning against treason were issued, the death penalty was frowned upon and the confiscation of property was rejected. However, no real legal

13. PAR, Zululand Administration (hereafter ZA) 33: The opinion of $H$ Bale on the crime of high treason, 1899-1900.

14. PAR, GH 1445: Minute paper W Hely-Hutchinson to AH Hime, 21.11.1899.

15. PAR, CO 179/216: Opinion on the confiscation of the property of rebels, 25.1.1900.

16. PAR, PM 17: Response to the question of confiscation posed by Yonge, 1.6.1900. 17. PAR, ZA 33: The opinion of $\mathrm{H}$ Bale on the crime of high treason, 1899-1900. 
suggestions on how to deal with the suspected rebels were forthcoming. One of the reasons for this was that Natal possessed a comprehensive treason law, Law No. 3 of 1868. This legislation was in line with the law of the United Kingdom pertaining to treasonable offences and contained an extensive definition of high treason, namely "overt acts or deeds" as well as treasonable acts by publishing or "open and advised speaking" of traitorous "compassings, imaginations, inventions, devices, or intentions". ${ }^{18}$ Law No. 3 of 1868, however, made no provision for the confiscation of the landed property of those found guilty of treason. When reviewing this law in August 1899, the Natal Legislative Assembly rejected the idea to amend it to allow for the confiscation of property. ${ }^{19}$ All in all, Law No. 3 of 1868 lacked real judicial power to deal with high treason within a context vastly different from when it had been passed 31 years before. Little wonder then that the magistrate for Ladysmith stated in his 1900 report,

I am of opinion that it would have been a kindness to these people had there been a stringent Rebellion Act in force; many would have hesitated to join the enemy had such an action jeopardised the safety of their landed property. ${ }^{20}$

Like the Natal Government, the British Army was unsure on how to deal with the suspected Natal rebels legally. The idea emanating from the Provost-Marshal's Office, based on the Roman Dutch Law by Van der Linden, was that the punishment for high treason "... is generally Death, and the manner and mode of execution is generally according to the greater or less degree of aggravating circumstances". 21 A circular memorandum, issued by General Lord Kitchener on behalf of the officer commanding of the British Army, Field Marshal Lord Roberts, however, provided greater clarity from the perspective of the military. It urged all involved in investigating treasonable charges to guard against political and personal bias and not to exhibit a feeling of sympathy or to sell articles to the Boer commandoes. Treasonable offences which were to be verified by impartial witnesses included preaching sedition and advising inhabitants to take up arms, giving information on troop movements, carrying arms against the British Army, and, more specifically, taking part in an attack on the British forces. $^{22}$ The argument that the Boers had annexed a certain district and that the

18. PAR, NCP 7/1/14: Natal Government Gazette, 22.9.1868.

19. Natal Legislative Assembly Debates, 22.8.1899.

20. PAR, NCP 8/1/11/3/2: Annual report Magistrate Klip River District, 1900.

21. National Archives Repository - Pretoria (hereafter NAR), Provost Marshal's Office (hereafter PMO) 2: Extract from Roman Dutch Law, p. 202, by Van der Linden, certified by Lt-Col NM Poole, no date.

22. PAR, CSO 2591: Circular memorandum issued by Lord Kitchener, 3.2.1900. 
inhabitants were forced to enlist were not to be accepted as a valid reason for committing treason. ${ }^{23}$ In contrast to the view of Attorney-General Bale, the memorandum deemed that, in exceptional cases, the commanding officer could, after a preliminary investigation, impose a death penalty. Under such circumstances, he had to apply for instructions from the commander-in-chief to arrange a trial for the offender before a commission existing of a judge of the Supreme Court and four commissioned officers. $^{24}$

The military practically applied the memorandum issued by Kitchener at the first possible opportunity. MP and GW de Jager, both Republican burghers, of Pietermaritzburg and Durban respectively, became the first two men to be sentenced for high treason under martial law by a Military Court in Natal. MP de Jager was originally arrested by a column under Brigadier-General JH Yule between Dundee and Ladysmith and imprisoned in Ladysmith during the siege, before being ordered to remain in Pietermaritzburg. A second attempt to reach the Boer lines, which involved crossing the Tugela River, failed as the De Jager's were arrested by African scouts and handed over to the military. ${ }^{25}$ Both were found guilty of breaching martial law and for attempting to enlist with the enemy. A Military Court under Maj-Gen Wolfe-Murray sentenced them to six months' imprisonment and a fine of $£ 50$ each, or a further one month imprisonment. ${ }^{26}$

At this stage, roughly six months into the war, with the Boer commandoes still in control of most of Northern Natal, a legal impasse of sorts existed. While the British Army and the Natal Government generally had the same idea regarding high treason and believed that confiscation was not a viable alternative, only the military had a legal structure - martial law supported by a memorandum issued by the officer commanding - in place. Apart from proposing a threatening proclamation and proclaiming martial law, not much legal progress was made by the Natal Government on how to deal with the suspected rebels.

23. Compulsion and lack of protection from the Natal authorities were the standard defence offered by many Natal Rebels. See OE Prozesky private collection, Diary of JJA Prozesky: Diary entry, 6.21901.

24. PAR, CSO 2591: Circular memorandum issued by Lord Kitchener, 3.2.1900.

25. PAR, Attorney-General's Office (hereafter AGO) 1/8/70: Papers relating to the arrest of MP and GW de Jager, 7.5.1900-12.5.1900.

26. PRO, WO 108/302: Extracts from the proceedings of the Military Court in Natal, 1900; PAR, PM 87: Sentences imposed by the Military Court on MP and GW de Jager, 29.6.1900-2.7.100. 


\section{The offensive of the British Army in Natal and the immediate results thereof}

On 11 May 1900, the British Army, under General Sir Buller, launched an operation with the aim of clearing the Klip River County from Boer commandoes. The arrest and prosecution of rebels was only a secondary military objective of this planned advance. Two months earlier, Buller had even expressed some sympathy with the rebels' plight and felt that "they really seem to have been more sinned against than sinning." 27 Buller, whose sentiments were probably coloured by previous positive dealings with Natal Afrikaners during the Anglo-Zulu and Anglo-Transvaal Wars twenty years earlier, informed Governor Hely-Hutchinson in a telegram dated 11 March 1900 of his views on how the suspected rebels should be treated. He suggested that they should be allowed to go back to their farms and that the Natal Government should treat them as suspects and have the police investigate them. Only once a case was built against them should they be arrested. At the same time he abdicated military involvement in dealing with the suspected rebels because he had neither the men nor the time to perform the required duties. The Natal authorities accepted these recommendations and instructed the Natal Police, from their bases outside the Boer occupied area, to intensify the preliminary gathering of information against suspected rebels. $^{28}$

On 1 May 1900, 10 days before the British Army advanced northwards, Buller announced his policy regarding the suspected Natal rebels. In his proclamation he stated that some of the Natal Afrikaners were misled into taking up arms, and having realised their error they were keen to redeem themselves. If they did do so, by laying down their weapons, he undertook to present their cases to the Natal authorities for more "considerate treatment" than extended to those who chose to remain in the field. ${ }^{29}$ The contents of Buller's proclamation infuriated the Natal Government who felt that he "had no business issuing such a proclamation without consulting the Governor of Natal". The second part, which promised "considerate treatment" especially, displeased the Natal Government for it bound them against their will. The government, possibly for the sake of diplomacy and to avoid conflict, did not confront Buller about his proclamation. $^{30}$

When the British Army finally advanced from Ladysmith via Helpmekaar to

27. PAR, PM 17: Telegram General R Buller to W Hely-Hutchinson, 17.5.1900.

28. PAR, CSO 2587: Telegram General R Buller to W Hely-Hutchinson, 11.3.1900.

29. PAR, GH 532: Proclamation issued by General R Buller, 11.5.1900; De Natal Afrikaner, 15.5.1900.

30. PRO, CO 179/212: Minute paper regarding the proclamation of General R Buller, 1.5.1900-13.6.1900. 
Dundee, several suspected rebels were arrested as the Boer commandoes retreated, principally by the advance parties of the Natal Carbineers. These arrests soon spread to Dannhauser and Newcastle. Some suspected rebels, like TR Boshoff and JJ Nel, possibly reacting to Buller's proclamation, surrendered of their own accord ${ }^{31}$ and received passes that allowed them to return to their farms. ${ }^{32}$ In the wake of these advance parties came the major body of the British Army, which swept the Klip River County clean of its Afrikaner residents. Between 10 May and early June 1900, 166 suspected rebels either surrendered or were arrested by the army. ${ }^{33}$ As a result of this campaign in which the military did police work, only one person, John Torpey, was found guilty of treason and convicted under martial law by a Military Court. Torpey, an English-speaking Newcastle trader who had formerly resided in the Orange Free State for 20 years, had done a roaring trade with the Boers during their occupation of Northern Natal. He was sentenced to five years' imprisonment with hard labour and a fine of $£ 100$ or a further year imprisonment. ${ }^{34}$ No Natal Afrikaners were, however, tried. They were shrewdly left for the civilian authorities to deal with.

Before long the prisons in Dundee and Newcastle found it impossible to hold all the suspected rebels, and between 30 May and 7 June 1900 a total of 74 were transferred to the central prison in Pietermaritzburg. Once Pietermaritzburg could no longer accommodate all of them, some were imprisoned on board the Catalonia outside the Durban harbour. ${ }^{35}$ The reasons offered by the military for transferring the suspected rebels included the dangers of having so many prisoners close to the front, the crowded nature of the local prisons, and the anticipation of further arrests and surrenders. ${ }^{36}$ All these measures, however, proved insufficient because of the sheer number of suspects arrested by or surrendering to the army. Consequently, some were allowed to reside in Newcastle with family members, in the local hotel, or in the vestry of the Newcastle Dutch Reformed Church on condition that they reported to the police twice a day. ${ }^{37}$

On arriving in Newcastle, Buller, true to his declaration of 11 March $1900,{ }^{38}$ that the civil authorities had to be empowered to deal with the suspected rebels, requested

31. Natal Witness, 6.6.1900.

32. Natal Witness, 25.5.1900.

33. PAR, AGO I/8/75: Disposal of treason cases in Natal, 10.10.1899-4.8.1900.

34. PAR, GH 502: Correspondence pertaining to the request by J Torpey for remission of sentence, 17.6.1901-24.7.1901; De Natal Afrikaner, 5.6.1900.

35. PAR, AGO I/7/46: Lists of Natal rebels captured from 10.5.1900-4.6.1900, compiled by Lt-Col AE Sandbach.

36. PAR, AGO I/8/70: Letter GL Fraser to H Bale, 2.6.1900.

37. OE Prozesky private collection, Diary of JJA Prozesky: Diary entries, 24.5.1900 and 30.5.1900.

38. PAR, CSO 2587: Telegram General R Buller to W Hely-Hutchinson, 11.3.1900. 
that the magistrates and their staff be returned. ${ }^{39}$ By then Magistrates $\mathrm{P}$ Hugo of Dundee and JO Jackson of Newcastle, both in exile in Southern Natal, were already, with the assistance of the Criminal Investigation Office (hereafter CIO), and based on the evidence of fellow exiles, busy compiling extensive lists of suspected rebels. ${ }^{40}$

Once Northern Natal was cleared of Boer commandoes, the Natal Police became the driving force behind the initial investigations against suspected Natal rebels arrested by the military. By 11 June 1900, a list with the names of 212 suspected rebels from the Dundee District, as well as witnesses, to testify against them, was in place. ${ }^{41}$

With the Klip River County cleared of Boers and suspected rebels, and the magistrates and the Natal Police busy with their investigations, Buller issued his final orders regarding the treatment of suspected rebels. These strategically timed and pragmatic orders decreed that all British subjects in the Klip River County would be required to register with the magistrates in their districts. On registration they had to sign either Declaration A or B. Declaration A was intended for those rebels suspected of taking up arms and such signatories were required to hand over their horses, arms, and ammunition and to sign a declaration stating, "I was forced by the Queen's enemies to take up arms against Her Majesty's Troops, and a rifle and ammunition were issued to me." The suspects who fell in this category could proceed to their farms on condition that they could be summoned at a later stage. They were also not allowed to communicate with or assist the Boers. ${ }^{42}$ If they claimed that they had handed their rifles to the Boers they were imprisoned until it could be proven that there were no arms on their farms. Natal Afrikaners within this group would eventually stand trial as rebels. Declaration B applied to British subjects who were required to bring two trustworthy witnesses before a magistrate to prove that they had remained absolutely loyal. ${ }^{43}$

Buller's orders, like his proclamation of 1 May $1900,{ }^{44}$ angered the Natal Government. This time around, with the military situation in the Colony under control, the Natal Government, by means of Attorney-General Bale, reacted confidently and confronted Buller complaining that the orders were in conflict with the Natal

39. PAR, PM 17: Telegram General R Buller to W Hely-Hutchinson, 17.5.1900.

40. PAR, CSO 2588: Request to P Hugo and JO Jackson to compile lists of suspected rebels, 5.5.1900.

41. PAR, AGO I/7/42: Letter Clarke to H Bale, 11.6.1900.

42. PAR, AGO I/7/42: Declaration A and B as issued by the British Army, 25.5.1900.

43. PAR, Ladysmith Magistrate (hereafter 1/LDS) 1/7/8: Orders General R Buller as relayed by Lt-Col AE Sandbach on the treatment of residents of Northern Natal, 28.5.1900.

44. PAR, GH 532: Proclamation issued by General R Buller, 11.5.1900; De Natal Afrikaner, 15.5.1900. 
Government proclamations issued in October 1899. Bale was also concerned that the oath in which the suspected rebels declared that they were forced to take up arms by the enemies of the Queen, would serve to prejudice the prosecution and that it may even place the onus to disprove the statement upon the crown, for under normal judicial circumstances the onus was on the prisoner to prove that he was compelled to take up arms. Even though Buller was prepared to apologise if his "non-legal" mind had prejudiced the process, he still believed that the onus was on the suspected rebels to prove their innocence. ${ }^{45}$

The fears of the Natal Government were, to a certain extent, allayed by Buller's intelligence officer, Lt-Col AE Sandbach, who informed the suspected rebels who, in terms of Buller's proclamation, were expecting to be released after handing in their weapons, that "each case must be considered on its merits and it is unadvisable on military grounds to release some of the suspected rebels on parole and the civil government must start the trials as soon as possible. ${ }^{, 46}$

This spat between the civil and military authorities on how to deal with the suspected Natal rebels was only the first of a series of such disagreements and served to highlight the differences in the organisational and legal cultures these two organisations represented. ${ }^{47}$ Especially the issue regarding the investigation of the suspected rebels initially arrested by the military, caused conflict. What made things even more difficult for the Natal Government was the fact that, under martial law, they were required to cooperate with the military in matters regarding the suspected rebels. ${ }^{48}$ Against this backdrop of simmering tension, the Natal authorities also had to deal with the pressure of another kind - the rabid and rampant jingoism amongst sectors of the Natal public, the English newspapers and certain organisations that insisted that a speedy justice be served on the suspected rebels.

\section{The Natal Government takes legal control}

The Times of Natal called upon all Natalians to gather as much evidence as

45. PAR, AGO I/8/71: Minute paper H Bale relative to the form of oath Natal rebels had to sign, 29.5.1900-1.6.1900.

46. PAR, Dundee Magistrate (hereafter1/DUN) 3/1/8: Letter Lt-Col AE Sandbach to Provost Marshal, 15.6.1900.

47. C Townshend, Martial Law: Legal and Administrative problems of civil emergency in Britain and the Empire, 1800-1940, The Historical Journal, 25/1, 1982, pp. 164194.

48. VS Harris, The reluctant rebels: The impact of the Second Anglo-Boer War upon the Klip River Dutch community, with special reference to the Dutch community of Dundee, p. 44. 
possible against suspected Natal rebels and to forward it to the government ${ }^{49}$ while the Natal Advertiser heavily criticised the idea that rebel property could not be confiscated. ${ }^{50}$ At the same time all major English newspapers published in Natal carried numerous letters demanding severe punishment for all rebels. ${ }^{51}$ The debate on what to do with the rebels continued outside the columns of the newspapers with the Lower Tugela Division Association urging the Natal Government to bring "rebels and traitors to justice". ${ }^{52}$ A similar call was forwarded on behalf of the Mid-Illovo Farmer's Club. ${ }^{53}$ These reactions and comments from the press and the public exerted enormous pressure on the Natal Government to not only to act decisively against the suspected rebels but also to exercise its authority and independence.

In addition to the tide of public criticism, the Imperial authorities in London voiced their scepticism regarding the actions of the Natal Government concerning the suspected rebels. What they really worried about was the high treason legislation, Law No. 3 of 1868 that was endorsed in August 1899 by the Natal Legislative Assembly. They doubted whether the Natal authorities and the local courts, using a jury system, would be able to deal with the suspected rebels justly. The Imperial Government furthermore desired a reasonably similar treatment of rebels in Natal and the Cape Colony, and to this end an "Imperial Special Commission" to try the rebels in both the colonies was suggested. ${ }^{54}$

At that stage, as a number of events unfolded concurrently, the Natal Government found itself in a pressure cooker situation - the Imperial authorities were distrusting their ability to deal fairly with the suspected rebels, the local voters and press were baying for blood, and they had to deal with the British Army who had arrested large numbers of suspected rebels and who had, under General Buller, steered the legislative process in a certain direction.

For the Natal Government, unlike for the British Army and the Imperial authorities, much more was at stake than merely trying rebels. For them it was an opportunity to defend the autonomy gained less than a decade before, in 1893, when responsible government was bestowed on the Colony. The trials of the suspected rebels were the

49. Times of Natal as quoted by De Natal Afrikaner, 13.10.1899.

50. Natal Advertiser, 7.6.1900.

51. See, for example, the Natal Witness, Times of Natal, Natal Advertiser, 27.3.1900, 29.3.1900, 31.3.1900 and 2.4.1900; PAR, PM 17: Letter WM Perry to AH Hime, 3.4.1900.

52. PAR, CSO 1644: Lower Tugela Division Association regarding the punishment of rebels, 4.4.1900.

53. PAR, CSO 1643: Resolution by the Mid-Illovo Farmers' Club, 19.4.1900.

54. PRO, CO 179/211: Telegram W Hely-Hutchinson to J Chamberlain, 12.5.1900. 
ideal opportunity to do this. The Natal Government was therefore determined to show its independence by dispensing justice on its subjects, and insisted that they would deal with the suspected rebels with a minimum "interference from the Imperial Government". As a government, they firmly believed that the existing system of administration of justice in Natal was adequate for the trial of rebels and "that the appointment of a judicial commission would be construed as a reflection upon the impartiality of our tribunals". 55 The Natal Government also made it clear that it was not possible to treat rebels in Natal and the Cape Colony in a similar fashion since for, unlike some districts in the Cape Colony, no district in Natal had suffered a revolt from the majority of its inhabitants. ${ }^{56}$ Governor Hely-Hutchinson therefore informed Colonial Secretary Joseph Chamberlain and High Commissioner Alfred Milner that "the circumstances in the Cape Colony and in Natal differ considerably and that to require uniformity of treatment of rebels would not be advisable." ${ }^{\circ 7}$

The Natal Government was, however, not united in its point of view. Ministers Moor and Smythe, who represented districts with large numbers of Afrikaner voters, supported the appointment of a judicial commission because they felt that juries would be swayed by their political sentiments. The other ministers considered such an appointment inadvisable as it would discredit the impartiality and competency of the judges in the Natal courts, the jingoistic public would regard it as a compromise in favour of the rebels, and the Natal Parliament would not pass such legislation. The counter-argument from Governor Hely-Hutchinson was that the failure to appoint such a commission in Natal might fail to secure the appointment of such a commission in the Cape Colony where juries were most likely to acquit rebels. The governor also drew the cabinet's attention to the fact that, if the rebel trials were moved from the predominantly Afrikaner districts, it would not look good, and that the number of court cases were too numerous to be handled by the Supreme Court. These arguments, however, failed to sway the majority of the cabinet, and consequently the only real firm decision taken was for the Attorney-General to prepare legislation that would allow magistrate courts to try less serious rebel cases. ${ }^{58}$ At that point, it was clear that the majority of the Natal Government were determined to hold out against the pressure to have rebels tried by a commission. By doing so they believed they were entrenching their own sovereignty and the independence of the judiciary ${ }^{59}$ while also appeasing the overtly jingoistic sections of the population and the press.

55. PRO, CO 179/211: Telegram W Hely-Hutchinson to J Chamberlain, 12.5.1900.

56. PRO, CO 179/211: Minute paper AH Hime to W Hely-Hutchinson, 3.3.1900.

57. PAR, CSO 2588: Telegram J Chamberlain to W Hely-Hutchinson, 31.3.1900.

58. PAR, GH 1302: Letter W Hely-Hutchinson to J Chamberlain, 14.4.1900.

59. PRO, CO 179/211: Letter W Hely-Hutchinson to J Chamberlain, 23.4.1900. 
Joseph Chamberlain, the Colonial Office, High Commissioner Milner and Governor Hely-Hutchinson all continued to put pressure on the Natal Government to agree to the appointment of a special commission. Eventually, on 24 April 1900, the Natal Government's resistance crumbled and it agreed, in some individual cases rather reluctantly, to appoint a special commission to conduct the trial of rebels. This change of opinion took place because of the immense pressure applied to ensure that "justice shall be done to rebels in the other parts of South Africa" but also because the British Army were on the verge of starting its advance on the areas of Natal occupied by the Republican forces which resulted, as explained earlier, in large numbers of suspected rebels being apprehended. This change of mind came with one condition - the majority of the commissioners for the Natal Court were to be appointed from the local bench and bar. ${ }^{60}$ This insistence caused a problem for it was suggested that British judges were to be employed as members of the commission. Again, despite claims that British judges were not acquainted with the procedure of law in Natal, that they had no knowledge of African customs and habits, and that it was a negative reflection on the impartiality and capacity of local judges and lawyers, the Natal Government relented and Sir William Smith from Britain was appointed as judge president. ${ }^{61}$

These ideological matters dealt with, the legal planning for the implementation of the special commission could start. ${ }^{62}$ The special commission to try the suspected Natal rebels took the form of a Special Court. ${ }^{63}$ Act 14 of 1900, stipulating "to make provision for the better and speedier trial of persons accused of treason, and for the appointment of acting Judges of the Supreme Court" was passed without much trouble by the Natal Parliament. The Act was promulgated on 31 July 1900, and came into effect the next day; ${ }^{64}$ roughly two months after the military had cleared Northern Natal of the Boer commandoes. The publication of the Act was followed by the publication of supporting legislation, namely Act 15 of 1900, which would serve to indemnify Natal authorities and the British Army regarding actions taken during the existence of martial law. ${ }^{65}$ Although the now legally constituted Special Court had to try all treason

60. PRO, CO 179/208: Telegram AH Hime to W Hely-Hutchinson, 24.4.1900; Letter W Hely-Hutchinson to J Chamberlain, 25.4.1900.

61. PAR, GH 1302: Telegram W Hely-Hutchinson to J Chamberlain, 30.5.1900; PRO, CO 179/208: Minute paper by $\mathrm{H}$ Bale on the commission to try rebels, 20.4.1900; PAR, GH 1302: Telegram W Hely-Hutchinson to J Chamberlain, 11.5.1900; PAR, AGO I/8/78: Minute paper H Bale to Minister of Lands and Works, 27.3.1901.

62. PAR, GH 1302: Telegram W Hely-Hutchinson to J Chamberlain, 11.5.1900.

63. PAR, GH 1456: Minute paper AH Hime to W Hely-Hutchinson, 20.4.1900.

64. PAR, NCP 6/1/1/53: Natal Government Gazette, 31.7.1900, containing Proclamation No. 56 of 1900.

65. PAR, NCP 6/1/1/53: Natal Government Gazette, 31.7.1900, containing Act 15 of 1900. 
cases, a provision was included so as to speed up the process and to deal with minor treasonable offences, for trial by a magistrate without jury. ${ }^{66}$ In a radical turnabout, the creation of the Special Court and the accompanying legislation defining high treason was welcomed by the normally very critical Natal newspapers. ${ }^{67}$

From the perspective of the Natal Government, they must have been very satisfied with how events turned out. As one of the smallest colonies in the British Empire, it had not only managed to stand up to the Colonial Office, but also to create the Special Court and, passing the accompanying legislation on high treason, it effectively cast aside the various orders and declarations earlier issued by Buller.

The Natal Government was, however, not being idle while the negotiations for the special commission and the assault on the Klip River County by the military were under way. In fact, they staged what was tantamount to show trials to appease the public and the press and to show the military and imperial authorities that they had the legal and administrative ability to deal with the suspected rebels. In the process, the Supreme Court of Natal and the Zululand High Court convicted four and two Natal Afrikaners respectively of high treason under Law No. 3 of 1868 in June $1900 .^{68}$

The Special Court inherited the legacy of the police work done by the military roughly five months earlier. The blanket arrest of suspected rebels by the military without any validation or evidence seriously hampered the investigations by the Natal Police and made it difficult to obtain depositions against the suspected rebels. ${ }^{69}$ As a result, the severely stretched Natal Police struggled. Inspector Clarke of the Natal Police provided a context to this legacy: "The persecution of rebels will be a lengthy business and very expensive ... I am sorry we cannot make more rapid progress with the work but I have been working 15 or 16 hours every day ...,"70

This inevitably meant that an already elaborate process became bogged down. On 18 October 1900, a worried Attorney-General Bale complained that the number of suspected rebels against whom no evidence had been obtained was unduly large. He also felt that it would be unfair to keep the men in prison for a period exceeding three months without any evidence against them. Bale was, however, also under political and

66. PAR, NCP 6/1/1/53: Natal Government Gazette, 31.7.1900, containing Act 14 of 1900; NCP 5/3/8: Colony of Natal Acts, Parliament of the Colony of Natal, $4^{\text {th }}$ session, second Colonial Parliament, 1900, Act 14 of 1900; Natal Witness, 24.5.1900.

67. Natal Witness, 26.5.1900; The Standard, 19.5.1900.

68. Natal Witness, 1.6.1900 to 15.6.1900; PAR, ZA 33: Enquiry into the advisability of prosecuting rebel cases outside of the constituted Special Court, 1.6.1900-21.6.1900. 69. PAR, AGO I/8/72: Application by NJ Degenaar to be released on parole or bail, 15.7.1900.

70. PAR, AGO I/7/42: Letter Clarke to H Bale, 11.6.1900. 
public pressure to speed up the proceedings. At the same time he was afraid that a critical Special Court would order the release of the suspects if steps were not immediately taken to justify their arrests. ${ }^{71}$ Bale consequently set a process in motion that could deal with the legacy of the arrests undertaken by the military. He doubled the number of assistant magistrates in the Klip River County, paid the clerks of the peace overtime, and had the details of the suspected rebels in custody forwarded to their home districts for investigation. ${ }^{72}$

However, a major problem faced by the police was that the military had earlier moved large numbers of suspected rebels from the Klip River County to prisons in Pietermaritzburg and Durban. The preliminary examinations could therefore not start until these suspected rebels were returned to the prisons in their home districts. What made matters worse was that these prisons were already overcrowded with more suspects arriving every day. ${ }^{73}$ The overcrowded prisons, the arrival of summer together with the slim chance of prospective evidence being unearthed convinced Henry Bale that bail should be granted to the imprisoned suspected rebels. ${ }^{74}$ Granting bail to suspected rebels however soon turned into a conflict between the Natal Government and the military. From the side of the military, the General Officer Commanding (hereafter GOC) for Natal, Lt-Gen Hildyard, had no objection to bail as long as the suspects did not reside in the Northern Natal districts affected by war. ${ }^{75}$

Soon afterwards, 30 suspected rebels released on bail were allowed, on the orders of the Attorney-General, to return to their farms in the Klip River County. ${ }^{76}$ From his side, Prime Minister Hime denied that the Natal Government had ever directly or indirectly authorised the return of suspected rebels to any area, which the military had not sanctioned. This denial settled the matter for Hildyard and the military sent a clear signal to the civil authorities - under martial law they had to decide who goes where regardless of the concerns of the Natal authorities. ${ }^{77}$ This hard line offended Attorney-

71. PAR, AGO I/8/75: Preparation of a complete list of rebels in prison arrested for treason, 9.10.1900-8.3.1901; AGO I/7/75: Letter H Bale to CIO, 25.10.1900.

72. PAR, AGO I/8/75: Complete list of rebels in prison arrested for treason, 9.10.1900-8.3.1901.

73. PAR, AGO I/8/75: Correspondence regarding a list of persons charged with high treason, 23.10.1900-25.10.1900.

74. PAR, AGO I/8/75: Letter H Bale to Minister of Lands and Works, 22.10.1900.

75. PAR, AGO I/8/75: Letter CA de R Labistour to H Bale, 29.11.1900.

76. PAR, 1/LDS 3/3/15: Correspondence between TR Bennett and DAAG Ladysmith, 22.12.1900-3.1.1901.

77. PAR, CSO 1732: Correspondence regarding the transfer of the Britz and Landman families from Newcastle to the Pietermaritzburg Concentration Camp, 23.6.190115.7.1901. 
General Bale for Hildyard's order was not communicated to the Natal Government directly while the decision could have a serious impact on the conditions of bail bonds agreed to by the Special Court. Although Bale conceded that the military could, under martial law, remove the suspected rebels on bail to any place they pleased, such a step would render all bail bond granted to suspected rebels inoperative. Bale thus suggested that the military require the men in question to report to some officer on a daily basis. The Natal Government therefore spelt out their position clearly to the military:

$\ldots$ it is very undesirable that there should be any apparent conflict between the Military and Civil Power. Your action will probably occasion the Government considerable inconvenience and may interfere with the administration of justice, which is the duty of both Departments to secure. ${ }^{78}$

The military, represented by Lt-Col Sim, offered an uncompromising military solution - the suspected rebels in question could be arrested under martial law if they were residing in an area without military consent. He also reiterated the military policy on the matter - no suspected rebel on bail is allowed to live north of Estcourt. Although the emphasis fell on men on bail, the military soon extended this order to all dubious Afrikaners, including convicted rebels who had served their sentences or who had paid their fines. All in all the military won the day and the Natal Police were instructed to facilitate the removal of the Afrikaners in question to the south of Estcourt. $^{79}$

Although it was not their primary task, the military continued to assist the Natal authorities in rounding up suspected rebels, particularly those who had fled to the Republics. ${ }^{80}$ However, cooperation between the Natal authorities and the military regarding suspected rebels who fell into the latter's hands was not always amicable. ${ }^{81} \mathrm{~A}$ group of 20 suspected rebels who surrendered to the military in the Vryheid District were a point in case. Suspects like these benefited from the fact that a lengthy period of time had elapsed since the Boer occupation of the Klip River County and that witnesses could in the meantime have forgotten what had transpired, or may have left the area.

78. PAR, AGO I/8/76: Correspondence on the removal of Afrikaners on bail from Dundee and Ladysmith, 24.12.1900-31.1.1901.

79. PAR, AGO I/8/76: Correspondence on the removal of Afrikaners on bail from Dundee and Ladysmith, 24.12.1900-31.1.1901.

80. PAR, AGO I/8/75: Application for bail by WH Boshoff, 21.11.1900; PAR, AGO I/8/83: List of untried prisoners charged with treason in the Dundee Prison, 27.12.1901.

81. NAR, PMO 39: Telegrams Provost Marshal Lt-Col RM Poole and GOC, Natal regarding the surrender of $\mathrm{N}$ and P Swart, 3.11.1901-4.12.1901. 
The burden of proof therefore shifted to military witnesses during the time of arrest or surrender. Attorney-General Bale for this reason requested the military to secure witnesses who could testify whether the suspects had actually committed high treason. ${ }^{82}$ With the assistance of the GOC Natal, orders were issued instructing officers to gather evidence on the spot when Natal rebels were apprehended. The names of witnesses who could testify about the circumstances under which the capture or surrender took place and whether the rebel carried arms, were to be especially noted. To assist the military in this process, the Natal Government from their side, forwarded lists with the names of suspected rebels unaccounted for to the Provost Marshal and military governor in Pretoria and the superintendents of concentration camps in the two Republics. ${ }^{83}$

It is difficult to determine the success of the orders issued by the GOC for the transfer of suspected Natal rebels from the military to the Natal authorities did not happen swiftly and the process was invariably accompanied by lengthy correspondence. ${ }^{84}$ On another level, namely calling witnesses related to the military to testify against suspected rebels, the relations between the Natal and military authorities were also strained. At times, both the defence and the prosecution had to trace military witnesses to give evidence. However, locating military witnesses and getting them to testify proved a laborious task that did not always meet with satisfaction, for example the difficulty in getting two members of the Volunteer Composite Regiment to testify against BG Meyer. Their commander, Colonel Evans, stated that his unit was under orders to move at an hour's notice and that they could be away from their base at Dundee for up to a month. Under these circumstances he could not grant the men leave to remain behind. The only option left to the civil authorities was to postpone the case until the witnesses were available. As a result, the case against Meyer only took place in March 1902, four months after the initial request was made. ${ }^{85}$ This was not a unique incident as the military generally proved to be an unreliable and indifferent partner in the prosecution of Natal rebels, resulting in the newly appointed Attorney-General, GA de R Labistour, having to request the newly appointed Governor, HE McCallum, to pressurise the army to secure military witnesses. ${ }^{86}$ The apathy of the military in

82. PAR, AGO I/8/79: Minute paper regarding surrender of Natal rebels at Vryheid, 28.3.1901-9.4.1901.

83. PAR, AGO I/8/78: Request by $\mathrm{H}$ Bale for military co-operation in obtaining evidence and witnesses in connection with rebels, 29.3.1901-28.5.1901.

84. PAR, PM 25: Minute paper by staff officer for POWs providing the names of alleged rebels, 3.12.1901-17.12.1901.

85. PAR, AGO I/7/37: Minute paper regarding members of the Volunteer Composite Regiment wanted as witnesses, 18.12.1901-12.8.1902.

86. PAR, AGO I/8/84: Minute paper GA de R Labistour to HE McCallum, 10.2.1902. 
providing witnesses could in all probability be blamed on the fact that, unlike in the Cape Colony, they were not trying the Natal rebels but had to hand them over to the civil authorities thereby leaving them without a vested interest in the legal process. ${ }^{87}$

Proof of this can be found in the fact that the military failed to apply martial law harshly where suspected Natal Afrikaner rebels were concerned, and in the end only seven were tried after the Boer occupation of Northern Natal had ended. Three of these, all of Dundee, were arrested for unpunctuality in reporting themselves and reprimanded. ${ }^{88}$ The other four rebels, who had already served sentences for high treason, were arrested on 22 November 1901 for being at the Pietermaritzburg Station without passes. They were handed over to the Natal authorities who fined each man, $£ 1$ or 10 days' imprisonment. The fines were paid the same day. ${ }^{89}$

Against the background of the aforementioned, it would be fair to say that the relationship between the Natal and military authorities, as far as prosecuting suspected rebels was concerned, was a mixture of conflict and cooperation. Despite this, the Special Court sat on 11 occasions between 16 September 1900 and 14 March 1902, ${ }^{90}$ and dealt with 596 individual cases. In total, 94\% of all Natal rebels convicted of high treason were dealt with by the Special Court and magistrates. In April 1902, the Special Court was dissolved and the remaining cases were remitted to a special magistrate for trial. ${ }^{91}$ However, an estimated 363 suspected rebels were still unaccounted for and little impact was made by the Natal authorities in apprehending them after this date. This was the case not only because of the time that had elapsed since the Boer occupation, but also because the rebels in question had managed to blend into the Boer commandoes. $^{92}$

Understandably then, by early 1902, with the British Army having a stranglehold on the Boer commandoes and the Natal Government feeling the same about their prosecution of the rebels, several Natal politicians were beginning to question the value of the continuation of martial law. ${ }^{93}$ This thinking was provided impetus by the military withdrawing from regions such as Greytown and Kranskop and handing over administration to the magistrates and Natal Police. To the relief of Prime Minister

87. PAR, PM 87: L of C orders No. 244, 4.7.1900.

88. Cd. 981: Papers relating to the administration of in South Africa, p. 191.

89. PAR, CSO 1692: Summary of convictions under martial law during December 1901, 21.12.1901.

90. PAR, AGO I/7/1-1/7/38: Judgments and sentences of Natal rebels by the Special Court, pp. 1-875.

91. PAR, CSO 1702: Letter AW Mason to HE McCallum, 18.4.1902.

92. PAR, AGO I/8/84: Memorandum GA de R Labistour to CIO, 1.3.1902.

93. PAR, PM 91: Letter AH Hime to HE McCallum, 14.2.1902. 
Hime, the overzealous ministers did not pursue the matter further and martial law remained. ${ }^{94}$

\section{Employing the Military Courts to deal with the remaining rebels}

Rather than scrapping martial law, a sentiment of using the military more effectively in the judicial process against the rebels started to take root. In October 1901, the commandant of Durban, Colonel O'Neill, proposed that Natal rebels be tried by Military Court rather than by the costly and time-consuming Special Court. Support for this idea came from Governor HE McCallum, who claimed that the public felt likewise. McCallum's canvassing for a change in the system was based on two reasons: the "easy life in prison" experienced by the sentenced rebels, and the fact that the suspected rebels still in the field had had ample opportunity to surrender, but chose not to do so and should therefore be banished to "convict establishments." McCallum's hard-line did not please the Natal Government who argued in favour of their creation, the Special Court. ${ }^{95}$

Governor McCallum, however, did not let the affair rest and raised the matter of how best to deal with the 300 plus suspected Natal rebels still in the field with High Commissioner Alfred Milner during the latter's visit to the Colony. ${ }^{96}$ When the latter adopted the same point of view as the Natal Government, McCallum decided to influence the process more directly. In conversation with the President of the Special Court, he took the opportunity to hint that "considering the heavy sentences which were now being passed by Military Courts in the Cape Colony, it would not be out of place if a somewhat greater severity characterised the sentences in this Colony." 97 As a result, McCallum had the satisfaction to report that his interference had resulted in heavier sentences being passed on at least two rebels. ${ }^{98}$

The mind of the Natal Government regarding the trying of suspected rebels apprehended outside the Colony by Military Court was changed by a single incident.

94. PAR, Kranskop Magistrate (hereafter 1/KRK) 3/1/4: Letter from officer commanding Umvoti to Magistrate at Kranskop, 28.2.1902. Martial law was eventually only repealed in Natal on 4.10.1902. See, De Natal Afrikaner, 10.6.1902.

95. PAR, GH 562: Minute paper regarding the suggested trial by court martial of rebels captured outside Natal, 7.10.1901-3.11.1901.

96. PRO, CO 179/220: Letter HE McCallum to J Chamberlain, 5.11.1901; Natal Witness, 26.10.1901.

97. At this stage, Military Courts in the Cape Colony were imposing prison sentences on rebels for periods likely to extend beyond the duration of the war, see NAR, PMO 52: Telegram GOC, Natal to Provost Marshal, 3.12.1901.

98. PAR, CO 179/220: Letter HE McCallum to J Chamberlain, 8.11.1901. 
Four suspected rebels, captured near Barberton, were handed over to the Natal authorities in July and August 1901. On 29 November 1901, the Natal CIO telegraphed the Provost Marshal asking if evidence could be supplied by the military against these men. The military's response was curt:

Evidence cannot now be produced and, as there was no doubt as to the Burghership of the men, it will be best instead of wasting more time to give them the benefit of the doubt and send them away as prisoners of war. ${ }^{99}$

In the meantime, the preliminary examination against the four had taken place and their cases were postponed awaiting the military evidence. The matter was eventually referred to the Attorney-General with the request that further investigations be suspended so that the four suspects could be deported, as suggested by the military. ${ }^{100}$

The bungling of the evidence in the above-mentioned case moved the issue of rebel trials from the political to the legal sphere. Attorney-General CA de R Labistour suggested pragmatically to Prime Minister Hime that the military should try all Natal suspected rebels caught or surrendering outside the Colony by court martial since this might prove easier than securing evidence from the military. The Natal Government adopted this suggestion without any resistance and approached Lord Kitchener via the office of Governor McCallum with the proposal. Kitchener agreed on condition that a "Bill of Indemnity" was passed to protect the military. The Natal Government acceded and subsequently passed Act No. 35 of 1902, which safeguarded the military against any post-war prosecution by rebels. Kitchener then, without delay, issued an order on 10 January 1902, informing officers that such trials could only take place with reference to the army head quarters. ${ }^{101}$

When prompted, Prime Minister Hime revealed the real reasons for capitulating and accepting a military justice approach towards the suspected rebels not yet apprehended. It had become increasingly difficult to obtain evidence because of the lapse of time. In addition, it was expensive to maintain the cumbersome Special Court, and the ruling that allowed the military to try suspected rebels by court martial would enable the Special Court to wind up its affairs and allow members of the court to return to their ordinary civil duties. ${ }^{102}$ Although not acknowledged by Hime, the Natal Government cleverly used the military to dispense justice to rebels where the Special

99. PRO, CO 179/222: Telegrams Provost Marshal to GOC, Natal, 7.1.1902.

100. PRO, CO 179/222: Telegrams Provost Marshal to GOC, Natal, 7.1.1902.

101. NAR, PMO 2: Telegram GOC, Natal, to Provost Marshal, Pretoria, 4.2.1902.

102. PRO, 179/222: Correspondence concerning the trial of Natal rebels by the military, 29.11.1900-4.1.1902. 
Court, as a Natal Government creation, could not reach administratively and legally.

The decision to allow the military to try suspected rebels arrested outside Natal effectively ended the protection the authorities gave their Afrikaner subjects against martial law. From the side of the military, Lt-Gen N Lyttelton, the GOC for Natal, suggested to Lord Kitchener, "if they really wanted to come in they will get comparatively lenient sentences". ${ }^{103}$ With this Kitchener concurred on condition that the suspected rebels were only guilty of rebellion. Lyttelton was, however, warned against issuing precise statements of possible punishment without consultation with the army headquarters. ${ }^{104}$

The comparatively lenient sentences Lyttelton hinted at proved to be false as several Natal Afrikaners soon found out. JC Boshoff of Newcastle, the first rebel to be sentenced under the new arrangement, was sentenced to 18 months' imprisonment and a fine of $£ 100$ or a further six months in prison. Suspected rebels subsequently arrested received even harsher sentences. On 13 February 1902, a Military Court in Standerton sentenced three rebels to six years' imprisonment each. In the process, IM Kok became the first Natal rebel to be sentenced to death for having two soft-nosed expanding bullets in his bandolier. Lord Kitchener eventually commuted his death sentence to a prison sentence. ${ }^{105}$ Another rebel, PJ Meyer, received an equally harsh sentence of five years' imprisonment and a fine of $£ 2000$ or a further three years' imprisonment from a Military Court sitting at Volksrust. ${ }^{106}$ All in all, the Military Courts convicted 15 Natal rebels, or $4 \%$ of the total number convicted of high treason, dishing out average sentences of four years and four months each. These sentences were generally much harsher than those passed by the Special Court. ${ }^{107}$

Once the war had ended, Attorney-General Labistour moved swiftly to end the trial of rebels by Military Court, especially after the army, in violation of the order that they

103. PRO, WO 108/116: Letter Lt-Gen N Lyttelton to Col I Hamilton, 14.2.1902.

104. PRO, WO 108/116: Letter Col I Hamilton to Lt-Gen N Lyttelton, 18.2.1902.

105. PAR, AGO I/8/84: Report on the conviction of J Kok, IM Kok and CJ Cronjé, 20.3.1902-20.6.1902. While 44 rebels were executed for high treason in the Cape Colony, none were executed in Natal. Jooste and Oosthuizen erroneously state that one or two Natal Afrikaners were executed after being tried by a Military Court. See G Jooste and A Oosthuizen, So het hulle gesterf. Gedenkboek van teregstellings van Kaapse Rebelle en Republikeinse Burgers tydens die Anglo-Boereoorlog 1899-1902, p. 252. The only report of a Natal Afrikaner, Judah Potgieter, receiving the death penalty is impossible to substantiate and is possibly nothing more than a rumour. See Natal Mercury, 30.11.1899.

106. PAR, AGO I/7/37: Confirmation of sentence imposed on PJ Meyer, 13.5.1902. 107. PAR, AGO I/8/86: Request that the accounting officer be informed of the costs involved in Military Court trials, 15.5.1902-24.5.1902. 
had to try rebels outside of Natal, brought three suspected rebels to Newcastle to be tried. By 9 September 1902, the trial of Natal rebels by Military Court had ceased and the seven untried prisoners were handed over to the Natal authorities to be tried by magistrates under the rules of the Special Court. ${ }^{108}$ This brought the cooperation and conflict between the Natal Government and the British Army on legal matters related to Natal rebel trials to a close.

\section{Conclusion}

The legal dealings surrounding the Natal rebels were a mammoth undertaking for the Natal Government who could, with good reason, take satisfaction in their achievement. With a small but competent and dedicated group of officials at the helm, they managed to defend the political autonomy of the Colony against the Imperial authorities, negotiated principles along which they wanted to dispense justice to suspected Natal rebels, generally pleased the jingoistic and prejudiced public and press, and by and large stood firm in numerous differences with the military on how the legal processes involving the rebels should unfold. At the same time they managed to maintain an independent stance on judging their subjects on their own terms despite being subservient to martial law.

For the British Army, on the other hand, the primary task was to win the war against the two Boer Republics. This revolved largely around military actions of which dispensing justice to rebels by means of martial law and though Military Courts was only one of the minor duties to be performed. In this process, conflict and cooperation with a small but very pushy Colony arose. A prime reason for this lies in the difference in organisational cultures the groups represented. While the civil authorities generally applied a transparent version of the law when dealing with the Natal rebels, the military could legitimately use their position of power under martial law not only to achieve quick legal solutions involving the rebels, but also to keep the Natal authorities at arm's length.

108. PAR, AGO I/8/85: Minute paper indicating that trial by Military Court had to cease and prisoners had to be handed over to the civil authorities, 22.8.1902-7.9.1902. 